\title{
A new genus of Dipnoiformes from the Cretaceous of Brazil
}

\author{
CARLOS E.V. TOLEDO ${ }^{1}$, ELIANE P. DE SOUSA ${ }^{2}$, MANUEL A.A. MEDEIROS ${ }^{3}$ and REINALDO J. BERTINI ${ }^{4}$ \\ ${ }^{1}$ USP/IGC/GSA, Rua do Lago, 562, Cidade Universitária, Butantã, 05508-080 São Paulo, SP, Brasil \\ ${ }^{2}$ UEMA/CECEN, Cidade Universitária Paulo VI, Bairro Tirirical, Caixa Postal 09, 65000-000 São Luís, MA, Brasil \\ ${ }^{3}$ Departamento de Biologia, Universidade Federal do Maranhão, Campus do Bacanga, \\ Avenida dos Portugueses, s/n, 65085-580 São Luís, MA, Brasil \\ ${ }^{4}$ UNESP/IGCE/DGA/NEPV, Avenida 24-A, 1515, Campus Rio Claro, Bairro Bela Vista, 13506-900 Rio Claro, SP, Brasil \\ Manuscript received on November 13, 2009; accepted for publication on March 1, 2011
}

\begin{abstract}
The Alcântara Formation, an important stratigraphic unit from the early Cenomanian of Brazil, was deposited under transitional (estuarine) conditions, and its fossil record includes fragmentary remains of plants, fishes, crocodylomorphs, pterosaurs and dinosaurs, with a noteworthy diversity of dipnoiformes tooth plates. The dipnoiformes material reported here comprises a new taxon, Equinoxiodus alcantarensis, gen. et sp. nov. Most of the identified morphotypes of continental vertebrates collected in the Alcântara Formation are similar to chronocorrelative faunas from Northern Africa, but this new genus of Dipnoiformes indicates some degree of paleogeographic isolation and endemism. This was probably caused by the widening of the equatorial Atlantic Ocean during the early Cenomanian, which may have selectively affected some species.
\end{abstract}

Key words: Dipnoiformes, neoceratodontids, Equinoxiodus alcantarensis gen. et sp. nov., Cretaceous.

\section{INTRODUCTION}

In 1994, a multiple layered bone-bed within iron-oxide cemented conglomeratic layers, alternating with sandstone levels, was discovered on the eastern side of the Cajual Island $\left(2^{\circ} 28^{\prime} 53,4^{\prime \prime} \mathrm{S}\right.$ and $\left.44^{\circ} 27^{\prime} 41,3^{\prime \prime} \mathrm{W}\right)$ in northern Maranhão State, northeastern Brazil (CorrêaMartins 1997). Measuring about four hectares in area, the bone-bed is exposed on a muddy beach, at low tide twice a day. The tidal range exceeds six meters causing the beach to be frequently swept by waves that expose and free up the fossils from the rock matrix. Traditionally deposits in this region were considered as belonging to the São Luís Basin. However, a stratigraphic revision undertaken by Góes and Rossetti (2001) demonstrated instead its continuity southward with sedimentary sequences of the Grajaú Basin (= northern Parnaíba Basin

Correspondence to: Manuel Alfredo Araujo Medeiros E-mail: alf@ufma.br sensu other authors), which led them to conclude that the two basins are in fact one, now so-called São LuísGrajaú Basin (Fig. 1).

The bone-bed (Fig. 2), named Laje do Coringa (Corrêa-Martins 1997), is a sequence within the Alcântara Formation (Itapecuru Group) located on the eastern beach of the Cajual Island. It is unique in Brazil because it crops out in a very restricted area exposed only during the low tide that has yielded thousands of bones, teeth and petrified plants as conifers and ferns. During the past 16 years, an impressive number of specimens has been collected and studied, revealing a noteworthy continental palaeobiota that includes fishes, crocodylomorphs, pterosaurs and dinosaurs. There is a remarkable number and diversity of dipnoiformes tooth plates, as well as some marine fishes and reptiles (Medeiros and Schultz 2001, 2002, 2004, Vilas Bôas and Carvalho 2001, Castro et al. 2004, Medeiros et al. 2007, Elias et al. 2007, Pereira and Medeiros 2008, Kellner et al. 2009). The 


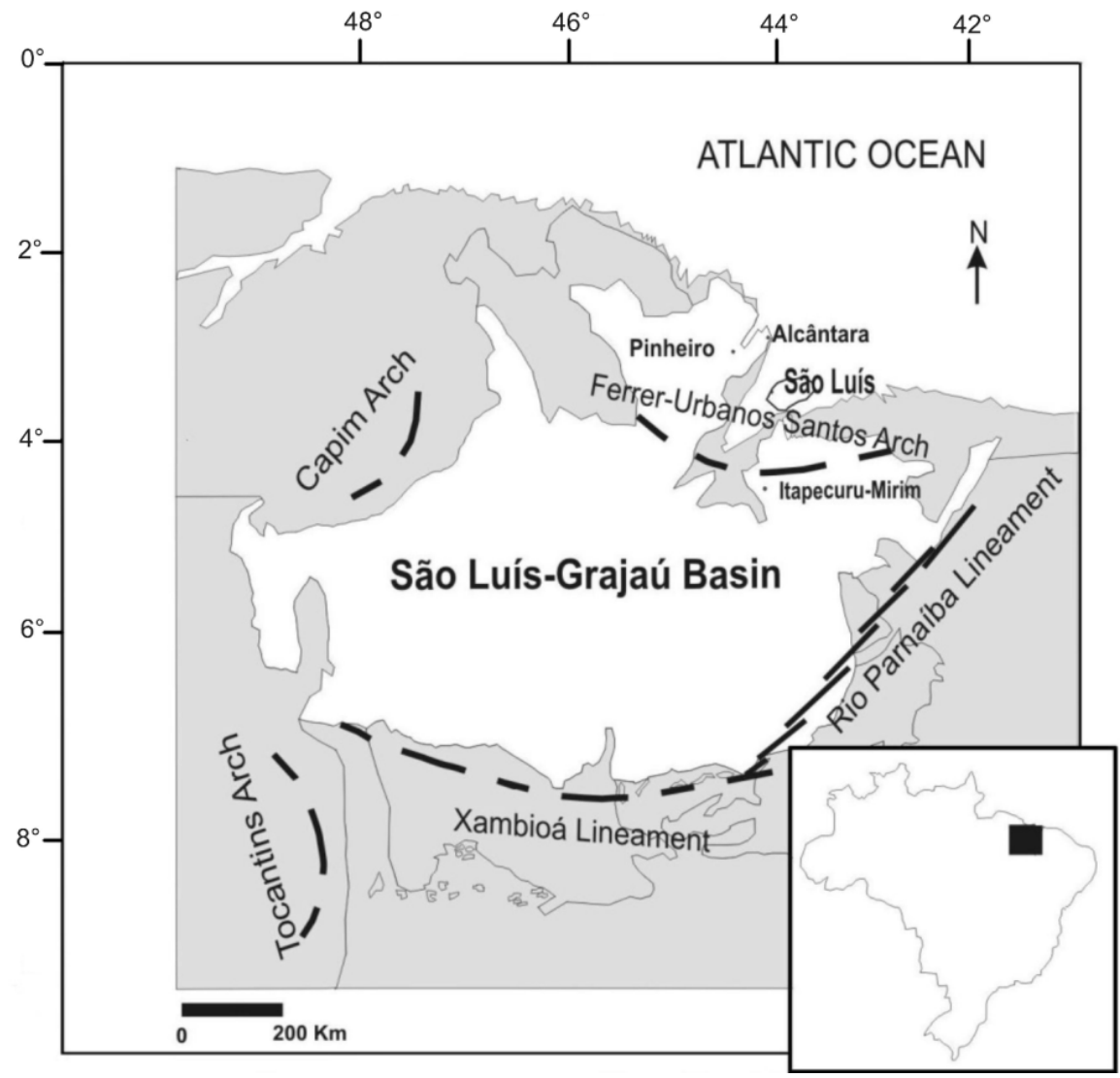

Fig. 1 - Map of Northern Maranhão state showing main geological landmarks of the São Luís Gajaú Basin, and the localization of the Alcântara Municipality (adapted from Rossetti 2003).

fossilization was mostly by permineralization of bones, teeth and tooth plates by iron oxides. This permineralization took place concomitantly with the lithification of the conglomerate, which was the result of iron oxides deposition (mainly goethite). Trunks of conifers and ferns were distinctly fossilized by a combination of silica and iron oxides and probably have a more complex taphonomic history.

The Itapecuru Group extends over the northern Maranhão State, covering an extensive area inland and along the shore. Albian and early Cenomanian deposits are well represented in this sedimentary sequence (Pedrão et al. 1993a, b, c). Numerous continental fossils have been recovered yielding much information about the northern South American environments, climate and faunas, while the western Gondwana was breaking apart. Laje do Coringa is thus far the richest fossiliferous site of the Itapecuru Group. It is formed by a few conglomeratic lenses, each one varying in thickness from less than one inch to about $15 \mathrm{~cm}$, intercalated by stratified sandstones. Holz (2003) considered the conglomerates as lags assembling continental fossil material reworked and re-deposited in marine sediments during a transgressive episode.

Regarding lungfishes, a noteworthy diversity of tooth plates has been collected and, thus far, some have been identified: Ceratodus africanus (or Ceratodus braziliensis sensu Cunha and Ferreira 1980), Asiatoceratodus tiguidiensis, and Ceratodus humei (Medeiros and Schultz 2001, 2002, Castro et al. 2004, Toledo et al. 2005). The present work deals with the morphological description and taxonomy of some tooth plates recovered from the Laje do Coringa, which are considered to represent a new genus and species of lung fishes.

\section{Geological Setting}

The richness of fossil deposits from the northern part of São Luis-Grajaú Basin is a consequence of the rapid sub- 


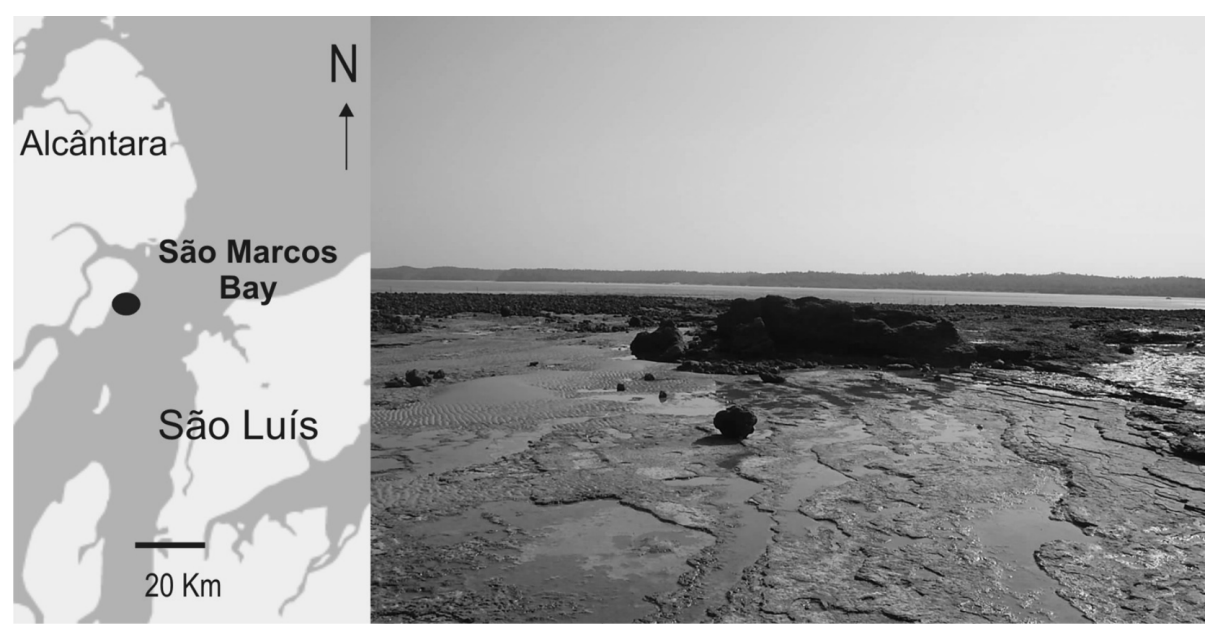

Fig. 2 - Localization of the Laje do Coringa fossiliferous site (black dot), and a photo showing the bone bed during low tide.

sidence of this region, which is situated on the Brazilian equatorial margin. The region was directly affected by rifting, which created a tectonic depression that was filled out by sediments of the Itapecuru Group. This group lies above Aptian strata of the Codó Formation. The Cretaceous sedimentary sequence of São Luís-Grajaú Basin records the South American-African breakup (Aranha et al. 1990, Góes and Feijó 1994, Góes and Rossetti 2001, Rossetti 2001). The upper sequences are divided into two transitional units: the Alcântara and Cujupe formations. The Alcântara Formation contains sequences that have been interpreted as an incised valley fill, which were deposited under a tide-dominated palaeoenvironment (Rossetti and Truckenbrodt 1997). This unit extensively outcrops in the coastal cliffs in São Marcos Bay, in the Alcântara City region (Fig. 2).

\section{DATING}

The palynological analysis of sediments in the coast of the São Luis Island indicates the early Cenomanian age in the outcropping Cretaceous sediments (Pedrão et al. 1993c). Klein and Ferreira (1979) also attributed a Cenomanian age to these deposits, based on bivalves from an estuarine facies. In fact, subsidence was more intense along the shore line in the early Cenomanian, resulting in faster and more massive accumulation of sediments in that region compared with deposition rates further inland (see revision in Rossetti et al. 2001).

\section{ENVIRONMENT AND Climate}

The palynological evidence for an arid tropical climate throughout the early Albian to early Cenomanian is provided by Pedrão et al. (1993a, b, c) and Rossetti and Toledo (1996), who studied sedimentary features in outcrops of the Alcântara Formation. This interpretation is reinforced by the study performed by Amiot et al. (2010) on Cretaceous material from Brazil and North Africa, which also evidences higher surface temperatures than present-day arid to semi-arid environments under tropical and equatorial climates. However, the record of conifer woods and giant ferns suggests the presence of forests, and fishes such as Mawsonia and Lepidotes give evidence of a substantial body of water in this region. Mawsonia could grow to a length of more than 3.5 meters, as evidenced by isolated bones from Laje do Coringa (to be published). Lepidotes would also require a considerable body of water to survive judging by the size of the scales found in the deposits. On the other hand, the dinosaurian fauna, which includes very large animals like the titanosaurs and rebbachisaurids, had to be supported by rich vegetation nearby. Rich vegetation would obviously require a relative high degree of humidity. In order to reconcile both aridity and humidity indicators in the same sedimentary sequence, the environment was interpreted as a conifer forest that would have been confined to the vicinity of fluvial canals and surrounded by an arid to semi-arid landscape (Medeiros and Schultz 2002). 


\section{Associated Paleofauna}

Although very fragmentary, fossils of Laje do Coringa are remarkably numerous. Teeth of some pterosaurs and dinosaurs can be found in their hundreds, while fish material like teeth and scales are counted in thousands. Dinosaurian vertebral centra are also a common item. Among sauropods, titanosaurids and a rebbachisaurid are present (Medeiros and Schultz 2002, 2004, Medeiros et al. 2007). Theropods are mainly identified on the basis of teeth, but some vertebral centra are also considered. Carcharodontosaurus is obviously present because its teeth are clearly diagnostic (Vilas Bôas et al. 1999). Spinosaurids are also listed, possibly represented by Spinosaurus itself (Medeiros and Schultz 2001, 2002). It is important to note that the fish and tetrapod taxa identified from Laje do Coringa represent a fauna similar to that from Albian and Cenomanian deposits in northern Africa (Medeiros and Schultz 2001, 2002). Many of the identified taxa from the Alcântara Formation are also recorded in that region of the African continent (e.g. Stromer 1915, 1931, 1934, Lapparent 1960, Tabaste 1963, Sereno et al. 1996, Russell 1996, Benton et al. 2000). The fish record is outstanding. Besides Dipnoiformes, the following genera have been identified: Lepidotes, Mawsonia, Bartschichthys, Stephanodus, Onchopristis and Atlanticopristis, along with pycnodontids and hybodontid sharks (Medeiros and Schultz 2001, Medeiros et al. 2007, Pereira and Medeiros 2008).

\section{Mesozoic Dipnoiformes From South AMERICA} AND AFRICA

Ceratodus iheringi, based on a single tooth plate from the Upper Cretaceous (Senonian) of Patagonia (Ameghino 1899, 1906), was the first record of Mesozoic Dipnoiformes in South America. To date, the record of Ceratodontiformes in Argentina ranges from late Cenomanian to late Campanian (Apesteguía et al. 2007). The oldest Mesozoic record in the South American continent is a single late Triassic dental plate identified as Ptychoceratodus cf. philippsi reported from the Santa Maria Formation (Richter and Toledo 2008). Further occurrences indicated the wide geographical range achieved by these fishes in western Gondwana during the Mesozoic, mainly in the Cretaceous. Dipnoiformes are represented by morphotypes referred to Ceratodontidae, Neoceratodontidae, Asiatoceratodontidae and Lepidosirenidae (Pascual and Bondesio 1976, Cunha and Ferreira 1980, Gayet and Brito 1989, Schultze 1991, Bertini et al. 1993, Silva and Azevedo 1996, Dutra and Malabarba 2001, Medeiros and Schultz 2001, 2002, Castro et al. 2004, Toledo et al. 2005, Apesteguía et al. 2007, Soto and Perea 2010). Neoceratodus would have had a widespread distribution on Gondwana in the Early Cretaceous, indicating an ancient origin to the group (Cavin et al. 2007).

In Africa, Mesozoic Dipnoiformes are represented by the same families. They are commonly found in the northern part of the continent (Peyer 1924, Tabaste 1963, Martin 1979, 1981, 1984a, b, Churcher 1999, Churcher and De Iullis 2001), where Cretaceous deposits are well represented.

Tabaste (1963) reported seven species from the Mesozoic deposits of the Sahara: Ceratodus africanus, C. humei, C. tuberculatus, C. pectinatus, C. tiguidiensis, C. protopteroides and Ceratodus sp. Some species were posteriorly revised by Martin (1984a), who reinterpreted $C$. tiguidiensis as Arganodus tiguidiensis, $C$. africanus as Neoceratodus africanus, C. tuberculatus as $N$. tuberculatus, and considered $C$. pectinatus as synonymous with $N$. africanus. He also reassigned $C$. humei to Protopterus humei (Martin 1984b). Arganodus tiguidiensis was posteriorly reassigned by Kemp (1998) to the genus Asiatoceratodus. Churcher and De Iullis (2001) retained $C$. humei's original assignment and reported the presence of the lepidosirenid Protopterus crasidens from the Cretaceous of Egypt. Churcher et al. (2006) erected the genus Retodus to accommodate specimens formerly referred to Ceratodus (or Neoceratodus) tuberculatus, and made reference to $C$. africanus as a valid taxon.

This instability of assignments is due to the difficulty in determining the taxonomic validity of many features and the extensive variation of some of them, as repeatedly stressed in the literature. Thus, the presence of the genera Ceratodus and Neoceratodus in the Cretaceous of Africa and South America depends on the authors' interpretation. 


\section{MATERIALS AND METHODS}

The tooth plates were either found lying around free from the host rock thanks to the erosive action of the sea waves or were collected by using traditional tools to release the specimens from the conglomerate. The material was analyzed in the laboratory of UNESP, in the city of Rio Claro.

The material collected at the Laje do Coringa fossiliferous site, Cajual Island, northern Maranhão State, northeastern Brazil (Figs. 1 and 2), comprises a series of 10 dipnoiformes isolated tooth plates with no supporting bones preserved. The specimens are deposited in the fossil collection of the Universidade Federal do Maranhão (UFMA), in the city of São Luis, Brazil.

\section{RESULTS}

The morphological analysis has shown that the specimens were representative of a genus of lungfishes that had already been recorded in the Paleocene of Bolivia (Schultze 1991), but was not named thus far. In the present work, we erect a new species and a new genus to accommodate this form of Dipnoiformes.

\section{Systematic Paleontology}

Subclass Sarcopterygii, Romer 1955

Infraclass Dipnoiformes, Cloutier 1992

Order Dipnoi, Müller 1846

Suborder Ceratodontoidei

Vorobyeva and Obruchev, 1964

Family ?Neoceratodontidae, Miles 1977

Equinoxiodus gen. nov.

Type species: Equinoxiodus alcantarensis sp. nov.

GENERIC Diagnosis as for type species

Equinoxiodus alcantarensis sp. nov. (Figs. 3, 4)

Flat plates without definable ridges and with slightly undulating occlusal surface. Four to five scarcely defined rounded indentations, drawing a wavy profile along the lateral margin in occlusal view. The ornamentation is an extensive network of reticulated fine lines formed by petrodentine, which extends from the labial to the lingual margin.
MATERIAL

Holotype: UFMA 1.40.086. Paratypes: one complete tooth plate (UFMA 1.40.060) and eight incomplete tooth plates (UFMA 1.40.042, UFMA 1.40.043, UFMA 1.40.062, UFMA 1.40.079, UFMA 1.40.087, UFMA 1.40.374, UFMA 1.40.465, UFMA 1.40.489).

Referred material: Schultze, H.-P. 1991: left prearticular tooth plate (Fig. 1), Left pterygoid tooth plate (Fig. 2) and right prearticular tooth plate (Fig. 3).

\section{DESCRIPTION}

The following descriptions mostly use, although not exclusively, the terminology revised by Churcher and De Iullis (2001).

Holotype: UFMA 1.40 .086 (Fig. 3A) is a complete, elongated, thin and almost flat tooth plate, measuring $82 \mathrm{~mm}$ in length and a maximum of $29 \mathrm{~mm}$ in width from the labial to the lingual margin, including the denticulations. It has no distinguishable crests or ridges, and the denticulations form a sinuous profile in occlusal view. The lateral margin exhibits posteriorly a curved contour, which meets the posterior limit of the lingual margin without abrupt angle. The denticulations follow a wavy pattern in lateral view. A complex network of anastomosed fine costae of petrodentine ("fine ridges" in the terminology of Schultze 1991) covers the entire crushing surface; most of them cross the plate labiallylingually, forming a network (Figs. 3A, 4C). These ornamental costae are also seen on the lingual margin. The punctuations are extensive over the entire surface, occurring on and between the costae. The lingual face exhibits a sulcus, which extends antero-posteriorly along most of its length.

Paratypes: UFMA 1.40 .060 is a complete specimen (Fig. 3B), measuring $63 \mathrm{~mm}$ in lenght and $22 \mathrm{~mm}$ in width, showing a concave mesial face on its oral margin. The lingual edge is progressively thicker anteriorly.

UFMA 1.40.465 is an incomplete specimen, $61 \mathrm{~mm}$ long (Fig. 3G). The oral margin of the mesial face is concave, becoming substantially thick aborally. In the position of the mesiointernal angle there is a peak shaped projection, directed almost perpendicularly in relation to the occlusal plan (Fig. 4B). 

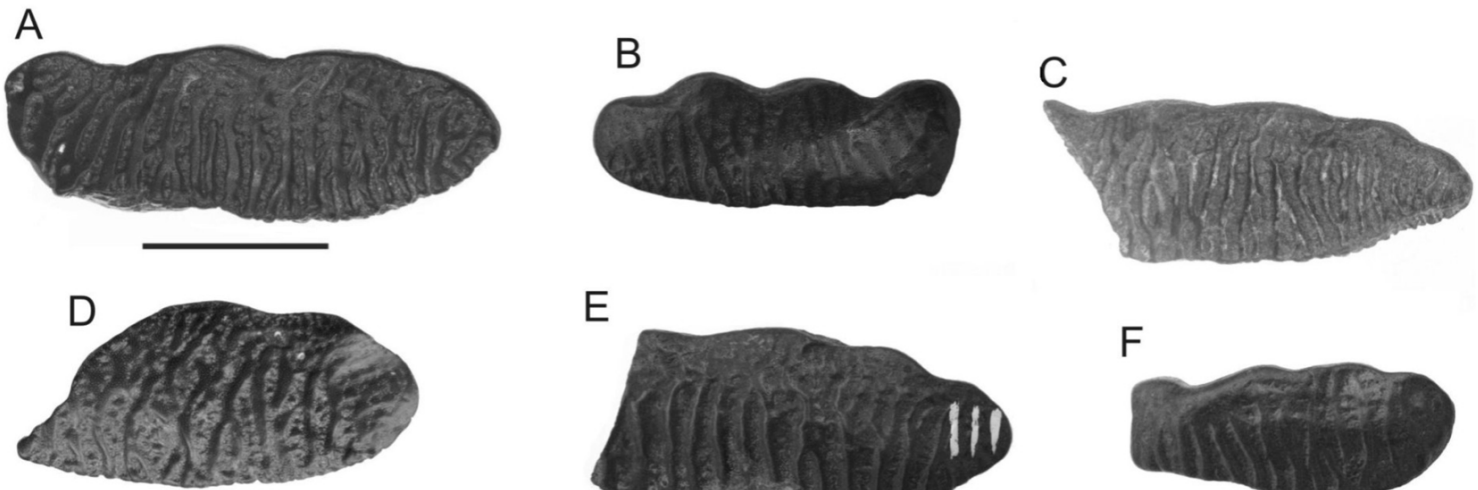

E
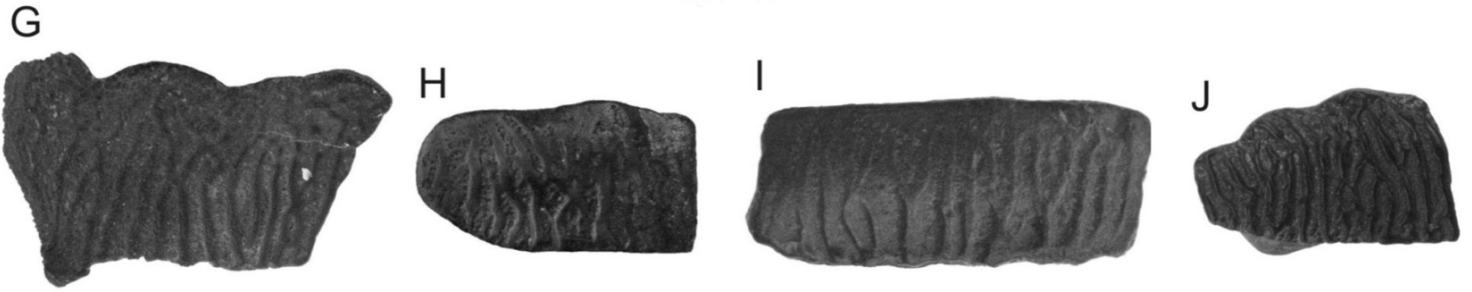

Fig. 3 - Equinoxiodus alcantarensis: A) Holotype, UFMA 1.40.086, B) UFMA 1.40.060, C) UFMA 1.40.079, D) UFMA 1.40.489, E) UFMA 1.40.042, F) UFMA 1.40.062, G) UFMA 1.40.465, H) UFMA 1.40.043, I) UFMA 1.40.374, J) UFMA 1.40.087. Descriptions in the text. Bar $=3 \mathrm{~cm}$.

\section{A}
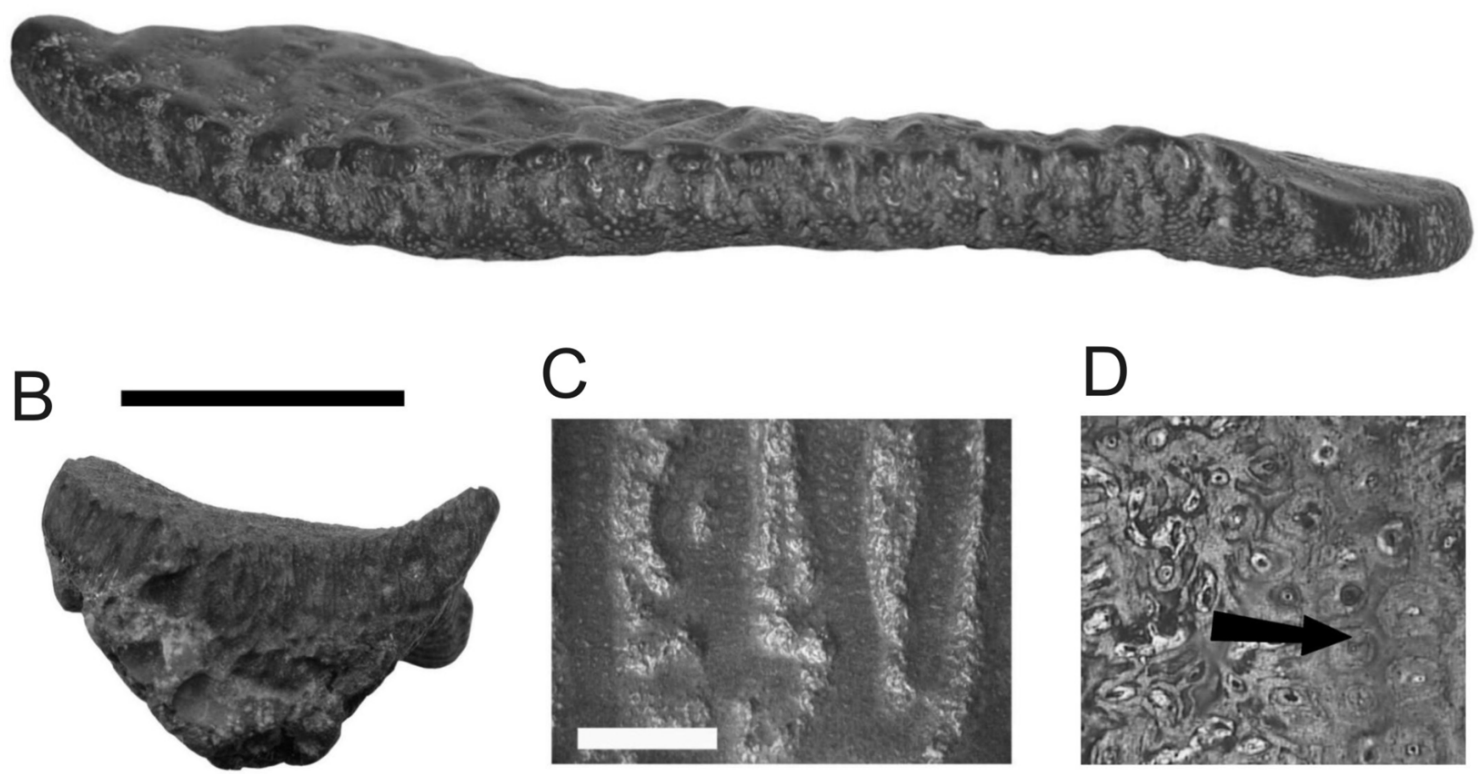

Fig. 4 -Equinoxiodus alcantarensis: A) UFMA 1.40 .489 in lingual view showing the undulating occlusal surface $($ bar $=3 \mathrm{~cm})$; B) mesial face of UFMA 1.40.465 (bar = 2 cm); C) Detail of ornamentation on the tooth plate UFMA 1.40.086 (bar = $5 \mathrm{~mm})$; D) Predominance of petrodentine on the fine lines (arrow) of the occlusal pitted surface $(50 \times)$. 
UFMA 1.40.079 (Fig. 3C), although incomplete, is the only specimen that bears five indentations. It is $65 \mathrm{~mm}$ in length and $26 \mathrm{~mm}$ in width.

Considering the whole type series, the outline of the plates is reminiscent of Archaeoceratodus djelleh (Kemp 1982, 1997), but the number and morphology of ridges and denticulations are different. The lateral denticulations in our sample are badly defined. The straight lingual margin curves slightly to the posterior extreme of the plate. The slightly undulating occlusal surface, as shown in Figure 4A (UFMA 1.40.489), seems to be original or caused by feeding habit; it is not the result of diagenetic deformation. The network formed by fine lines of petrodentine (Figs. 4C, D) is a feature that distinguishes these plates from all other previously described dipnoans from the Alcântara Formation.

The tooth plates underwent a significant postmortem abrasion. Nine of the specimens did not keep any attached bone; the exception is UFMA 1.40.087, a distal half of a plate (Fig. 3J), which exhibits a very small, abraded and unidentifiable bone fragment. So, we prefer not to speculate about the original position of the plates.

\section{LOCALITY AND HORIZON}

Laje do Coringa site, Cajual Island $\left(2^{\circ} 28^{\prime} 53.42^{\prime \prime} \mathrm{S}\right.$; $\left.44^{\circ} 27^{\prime} 41.32^{\prime \prime} \mathrm{W}\right)$, Municipality of Alcântara, northern Maranhão State, northeastern Brazil. Itapecuru Group, Alcântara Formation, early Cenomanian, Late Cretaceous.

\section{ETHYMOLOGY}

"Equinoxi" as a reference to the France Equinoxialis, the name given to the northern Maranhão state in 1612; "odus" from the latinised Greek word for tooth; "alcantarensis" in reference to Alcântara, the town where the type material was collected.

\section{DISCUSSION}

Equinoxiodus alcantarensis gen. et sp. nov. shows parallel pulpar canals similar to those in the families Ceratodontidae and Neoceratodontidae (see Smith 1984), as well as petrodentine and circumpulpar dentine.

The petrodentine is translucent under polarized light and shows lower birefringence with colors of first order from grey to pale yellow, weak pleochroism and texture fibers that grows from the pulpar canal, parallel extinction and negative elongation. The size of the chrystalites in the petrodentine is around $0.2 \mathrm{~mm}$, and the diameter of the pulpar canals varies from 0.04 to $0.08 \mathrm{~mm}$. The pulpar canals are filled by hematite and goethite.

The circumpulpar dentine shows weak birefringence, which is lower than that of the petrodentine with first order color from gray to light gray, sometimes pale yellow. The dentine grows concentrically around the pulpar canal and shows a granular texture. Locally, the dentine shows high cristalinity and higher relief that corresponds to higher birefringence.

The dentine tubules are $0.075 \mathrm{~mm}$ long, and their width range from 0.04 to $0.1 \mathrm{~mm}$.

The tooth plates of Equinoxiodus gen. nov. do not exhibit diagnostic features to conclusively allocate it in any known family of dipnoans. It is tentatively assigned to the Family Neoceratodontidae based on (a) the parallel pulpar canals (Fig. 5), (b) the presence of petrodentine (Figs. 4D and 5) and (c) its elongated profile, similar to Archaeoceratodus, in spite of the difference in the number of denticulations.

The complex ornamentation seen on the crushing surface of this new species and genus is similar to the specimen described by Schultze (1991) from the Santa Lucia Formation, Paleocene of Bolivia. Schultze (op. cit.) considered the protuding "fine ridges" observed on the specimens as a major distinctive feature, proposing that the material should be allocated into a new genus, although he did not name it.

Here we ascribe the Santa Lucia Formation tooth plates to the genus Equinoxiodus gen. nov. Therefore, the temporal range of this genus spans from early Cenomanian to early Paleocene.

Considering that South America and Africa were connected until late Albian (Reyment and Dingle 1987, Koutsoukos et al. 1991), it is not unexpected that the paleocommunities recorded in northeastern Brazil, and all along northern Sahara, are somehow similar as evidenced by the Alcântara Formation record (Medeiros and Schultz 2001, 2002). The early Cenomanian continental Moroccan fish fauna of Kem Kem has been considered as similar to the South American record (Cavin and Dutheil 1999; see also Cavin et al. 2010). 


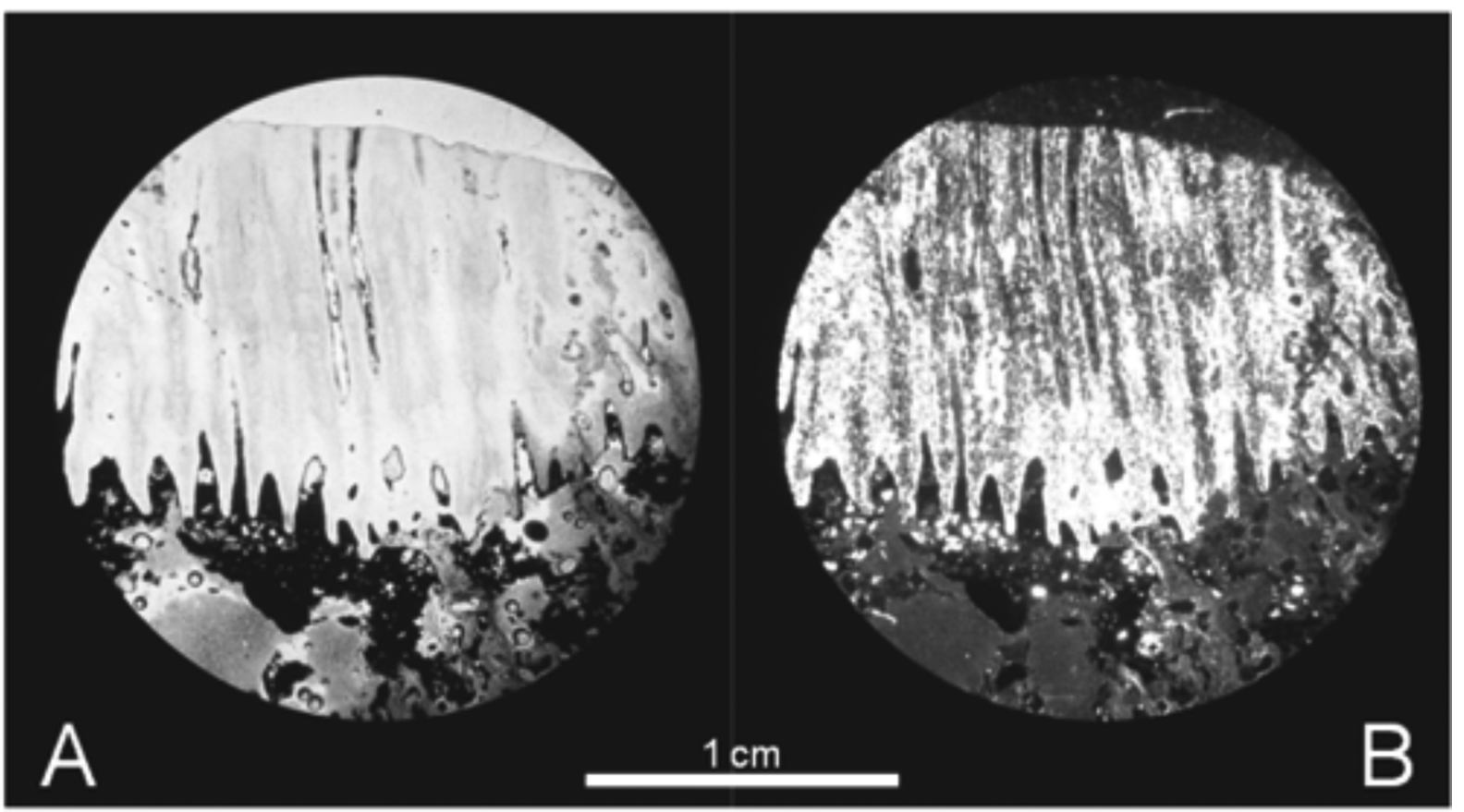

Fig. 5 -Equinoxiodus alcantarensis: Vertical section through the central region of the tooth plate showing the parallel pulpar canals from the pulp chamber to the tritural surface. A) ordinary light. B) polarized light.

Regarding dipnoiformes, Schultze (1991) considered ceratodontids euryhaline, justifying the occurrence of the group on both sides of the equatorial South Atlantic Ocean. The new species described in the present work, considered as neoceratodontid, is not recorded in Africa. Therefore, one can speculate that either the species was not able to tolerate saline conditions, which would be an impediment to crossing even the narrow South Atlantic Ocean, or other barriers to its dispersal, not registered in the geologic record, were in operation to prevent it reaching Africa. Maisey (2000) stated that tectonic events involved in the opening of the equatorial Atlantic Ocean also provided opportunities for local vicariance even before the seaway development. This could also be a reasonable explanation to the rising of the endemic fish taxon described here. In any case, this new record provides evidence that an effective isolation factor affecting at least some species was present by the early Cenomanian. Even in the event of a purported persistent transoceanic connection between South America and Africa through a narrow and shallow ocean (Cox 1980, Rage 1988, Buffetaut and Rage 1993, Sereno et al. 2004), this would still probably represent a selective barrier for certain species.

\section{CONCLUSIONS}

Although the similarities observed in the recorded transatlantic faunal elements are obviously resultant of the major vicariant event that separated Gondwanan landmasses, the presence of dinosaur genera common to the continents of either side of the Atlantic Ocean in the Cenomanian reinforces the idea that South American and African populations would have maintained interchanges until the end of the Early Cretaceous or even until the Cenomanian (Medeiros and Schultz 2002, see Sereno et al. 2004). However, the fossil record from the Laje do Coringa bone-bed in Brazil also includes apparently endemic taxa like the new dipnoiformes described here, namely Equinoxiodus alcantarensis gen. et sp. nov. This suggests some degree of isolation involving South American and African paleofaunas by the early Cenomanian. These two apparently conflicting pieces of evidences can be reconciled by assuming a selective transatlantic connection and an effective isolation for some taxa not able to cross the marine barrier.

Ceratodontids were considered to be euryaline (Schultze 1991), and able to cross the equatorial South Atlantic Ocean, but different species of continental wa- 
ter fishes, including dipnoans, may have had different degrees of response to the isolation by a narrow marine environment, as possibly also terrestrial vertebrates. Equinoxiodus alcantarensis gen. et sp. nov., here considered a neoceratodontid, was probably a fresh water fish with no adaptations to cross a marine barrier and thus not able to reach Africa.

\section{ACKNOWLEDGMENTS}

We thank the students of the Biological Sciences Course of the Universidade Federal do Maranhão (UFMA) for helping to collect the material studied here. We also thank Dr. C.S. Churcher for constructive criticism and suggestions. Financial support was provided by: Universidade Federal do Maranhão (UFMA), Universidade Estadual Paulista (UNESP), Coordenação de Aperfeiçoamento de Pessoal de Nível Superior (CAPES), Petróleo Brasileiro S.A. (PETROBRAS).

\section{RESUMO}

A Formação Alcântara, uma importante unidade estratigráfica do início do Cenomaniano no Brasil, foi depositada sob condições transicionais (estuarinas), e o seu registro fóssil inclui restos fragmentários de vegetais, peixes, crocodilomorfos, pterossauros e dinossauros, com uma notável diversidade de placas dentárias de dipnoiformes. O material de dipnoiformes aqui reportado compreende um novo taxon, Equinoxiodus alcantarensis gen. et sp. nov. A maioria dos morfótipos de vertebrados continentais coletados na Formação Alcântara são similares a faunas cronocorrelatas do norte da África, mas este novo gênero de Dipnoiformes indica algum grau de isolamento paleogeográfico e endemismo, provavelmente causado pelo alargamento do Oceano Atlântico equatorial no início do Cenomaniano, que pode ter afetado, de forma seletiva, algumas espécies.

Palavras-chave: Dipnoiformes, neoceratodontídeos, Equinoxiodus alcantarensis gen. et sp. nov., Cretáceo.

\section{REFERENCES}

Ameghino F. 1899. Sinopsis Geológico-Paleontológica de La Argentina. Censo Nacional de la Republica Argentina, 2, 1899. La Plata, Argentina. Suplemento. La Plata: Republica Argentina, p. 1-13.

Ameghino F. 1906. Las formacions sédimentaires du Cretacé Supérieur et du Tertiaire du Patagonie, avec un paral- léle entre leur faunes mammalogiques et celles de l'ancient continent. An Mus Nac Hist Nat Buenos Aires 15(8): $1-568$.

Amiot R ET AL. 2010. Oxygen and carbon isotope compositions of middle Cretaceous vertebrates from North Africa and Brazil: ecological and environmental significance. Palaeogeogr Palaeoclimatol Palaeoecol 297(2): $439-451$.

Apesteguía S, Agnolin FL and Claeson K. 2007. Review of Cretaceous dipnoans from Argentina (Sacopterygii: Dipnoi) with descriptions of new species. Rev Mus Argent Cienc Nat N S 9(1): 27-40.

Aranha LG, Lima HP, Souza JMP AND MAKino RK. 1990. Origem e evolução das bacias de Bragança-Viseu, São Luís e Ilha Nova. In: GABAGLIA GPR AND MILANI EJ (Eds), Origem e Evolução de Bacias Sedimentares, Rio de Janeiro: Petrobras, p. 221-233.

Benton MJ, Bouaziz S, Buffetaut E, Martill D, Ouaja M, Soussi M and Trueman C. 2000. Dinosaurs and other fossil vertebrates from fluvial deposits in the Lower Cretaceous of southern Tunisia. Palaeogeogr Palaeoclimatol Palaeoecol 157: 227-246.

Bertini RJ, Marshall LG, Gayet M and Brito P. 1993. Vertebrate faunas from the Adamantina and Marília formations (Upper Bauru Group, Late Cretaceous, Brazil) in their stratigraphic and paleobiogeographic context. Neues Jahrb Geol Paläontol Abh 188(1): 71-101.

Buffetaut E AND RAGE JC. 1993. Fossil amphibians and reptiles and the Africa-South American connection. In: George W and Lavocat R (Eds), The Africa-South America Connection, Oxford; New York: Clarendon Press, p. 87-99.

Castro DF, Toledo CEV, Sousa EP And Medeiros MA. 2004. Novas ocorrências de Asiatoceratodus (Osteichthyes, Dipnoiformes) na Formação Alcântara, Eocenomaniano da bacia de São Luís, MA, Brasil. Rev Bras Paleontol 7(2): 245-248.

CAVIN L AND Dutheil DB. 1999. A new Cenomanian ichthyofauna from southeastern Morocco and its relationships with other early Late Cretaceous Moroccan faunas. Geol Mijnb 78: 261-266.

Cavin L, Suteethorn V, Buffetaut E And Tong H. 2007. A new Thai Mesozoic lungfish (Sarcopterygii, Dipnoi) with an insight into post-Palaeozoic dipnoan evolution. Zool J Linn Soc 149: 141-177.

CAVIN L ET AL. 2010. Vertebrate assemblages from the early Late Cretaceous of southeastern Morocco: an overview. J Afr Earth Sci 57: 391-412. 
Churcher CS. 1999. A note on the Late Cretaceous vertebrate fauna of the Dakhleh Oasis. In: CHURCHER CS AND Mills AJ (Eds), The Dahkleh Oasis Project: Reports from the Survey of Dakhleh Oasis, western desert of Egypt, 1977-1987. Kakhleh Oasis Monograph 2, Oxbow Monogr. 99, Oxford: Oxbow Books, p. 55-67.

Churcher CS And De Iullis G. 2001. A new species of Protopterus and a revision of Ceratodus humei (Dipnoi: Ceratodontiformes) from the Late Cretaceous Mut Formation of eastern Dakhleh Oasis, western desert of Egypt. Paleontology 44(2): 305-323.

Churcher CS, De IUllis G and Kleindienst Mr. 2006. A new genus for the dipnoan species Ceratodus tuberculatus Tabaste, 1963. Geodiversitas 28(4): 635647.

CORRÊA-MARTINS FJ. 1997. A Laje do Coringa: um bonebed da Formação Itapecuru (Cretáceo Superior da Bacia de São Luís - MA). An Acad Bras Cienc 63: 436-437.

Cox CB. 1980. An outline of the biogeography of the Mesozoic World. Mem Soc Geol Fr 139: 75-79.

CUNHA FLS AND FerReIRA CS. 1980. Um dipnoi na Formação Itapecuru (Cenomaniano), Maranhão, Brasil. In: Congreso Argentino de Paleontologia y Bioestratigrafia, 2, Buenos Aires. Actas, Buenos Aires: APA, p. 1-9.

Dutra MFA and Malabarba MC. 2001. Peixes do Albiano-Cenomaniano do Grupo Itapecuru no Estado do Maranhão, Brasil. In: Rosseti DF, Góes AM AND Truckenbrodt W (Eds), O Cretáceo da Bacia de São Luís-Grajaú, Belém: Mus Para Emílio Goeldi, p. 191208.

Elias FA, Bertini RJ and Medeiros MA. 2007. Pterosaur teeth from the Laje do Coringa, middle Cretaceous, São Luís-Grajaú Basin, Maranhão, Northern-Northeastern Brazil. Rev Bras Geoc 37: 1-9.

GAYET M AND BRITO PM. 1989. Ichtyofaune nouvelle du Crétacé Supérieur du Groupe Bauru (états de São Paulo et Minas Gerais, Brésil). Geobios 22(6): 841-847.

Góes AM And Feijó FJ. 1994. A Bacia do Parnaíba. Bol Geoc Petrobras 8(1): 57-67.

Góes AM And Rossetti DF. 2001. Gênese da Bacia de São Luís-Grajaú. Meio Norte do Brasil. In: Rossetti DF, Góes AM AND TRuckenbrodt W (Eds), O Cretáceo na Bacia de São Luís-Grajaú, Belém: Mus Para Emilio Goeldi, p. 15-29.

Holz M. 2003. Sequence stratigraphy as a tool for Vertebrate Taphonomy. An example from a Late Cretaceous dinosaur taphocoenosis from São Luís Basin, Northern
Brazil. In: LATIN AMERICAN CONGRESS Of SEDIMENTOLOGY, 3, Belém. Abstracts, Belém: Mus Para Emílio Goeldi, p. 213-214.

Kellner AWA, Pinheiro AEP, Azevedo SAK, HenRIQUES DDR, CARVALHo LB AND OliveIRA GR. 2009. A new crocodiliform from the Alcântara Formation (Cenomanian), Cajual Island, Brazil. Zootaxa 2030: 49-58.

KeMP A. 1982. Neoceratodus djelleh, a new ceratodont lungfish from Duaringa, Queensland. Alcheringa 6: 151-155.

KemP A. 1997. A revision of Australian Mesozoic and Cenozoic lungfish of the family Neoceratodontidae (Osteichthyes: Dipnoi), with a description of four new species. J Paleontol 71(4): 713-733.

KEMP A. 1998. Skull structure in post-Paleozoic lungfish. J Vert Paleontol 18(1): 43-63.

KLeIN VC AND Ferreira CS. 1979. Paleontologia e Estratigrafia de uma fácies estuarina da Formação Itapecuru, Estado do Maranhão. An Acad Bras Cienc 51: 523-533.

Koutsoukos EAM, Destro N, Azambuja Filho NC, Hart MB AND MaXwell JR. 1991. The upper Aptian-Albian sucession of the Sergipe Basin, Brazil: an integrated paleoenvironmental assessment. AAPG Bull 75(3): 479-498.

LAPPARENT AF. 1960. Les dinosauriens du "Continental Intercalaire" du Sahara Central. Mem Soc Geol Fr, NS 88(A): $3-56$

Maisey JG. 2000. Continental break up and the distribution of fishes of Western Gondwana during the Early Cretaceous. Cret Res 21: 281-314.

Martin M. 1979. Arganodus atlantis et Ceratodus arganensis, deux nouveax Dipneustes du Trias supérieur continental marocain. C R Acad Sci Paris, Ser. D 289: 89-92.

MARTIN M. 1981. Les Ceratodontiformes (Dipnoi) de Gadoufaoua (Aptien supérieur, Niger). Bull Mus Natl Hist Nat, Paris, $4^{\text {ème }}$ Ser., 3. section C, n. 3, p. 267-283.

MARTIN M. 1984a. Révision des Arganodontidés et des Néocératodontidés (Dipnoi, Ceratodontiformes) du Crétacé africain. Neues Jahrb Palaeontol Abh 169(2): 225260.

MARTIN M. 1984b. Deux Lepidosirenidae (Dipnoi) crétacés du Sahara, Protopterus humei (PRIEM) et Protopterus protopteroides (TABASTE). Paläontol Z 58: 265-277.

Medeiros MA, Freire PC, Pereira AA, Santos RAB, Lindoso RM, Cốlho AF, PAssos EB And Sousa JÚNIOR E. 2007. Another African dinosaur recorded in the Eocenomanian of Brazil and a revision on the paleofauna of the Laje do Coringa site. In: CARVALHO IS, 
Cassab RCT, Schwanke C, Carvalho MA, FerNANDES ACS, Rodrigues MAC, CARVAlHo MSS, ARAi M AND Oliveira MEQ (Eds), Paleontologia: Cenários de Vida, Rio de Janeiro: Interciência, p. 413423.

Medeiros MA AND SChultz CL. 2001. Uma paleocomunidade de vertebrados do Cretáceo médio, bacia de São Luís. In: Rossetti DF, Góes AM AND TRUCKEnBRODT W (Eds), O Cretáceo na Bacia de São Luís - Grajaú, Belém: Mus Para Emílio Goeldi, p. 209-221.

Medeiros MA ANd Schultz CL. 2002. A fauna dinossauriana da Laje do Coringa, Cretáceo Médio do Nordeste do Brasil. Arq Mus Nac 60 (3): 155-162.

Medeiros MA and Schultz CL. 2004. Rayososaurus (Sauropoda, Diplodocoidea) no meso-Cretáceo do NorteNordeste Brasileiro. Rev Bras Paleontol 7(2): 255-279.

PASCUAL R AND BONDESIO P. 1976. Notas sobre vertebrados de la frontera cretacica-terciaria. III: Ceratodontidae (Peces Osteichthyes, Dipnoi) de la Formacion Coli-Toro y de otras unidades del Cretacico Tardio de Patagonia y sur de Mendoza. Sus implicancias paleobiogeograficas. In: Congreso Geologico Argentino, 6, Bahía Blanca, Actas Tomo I. Bahía Blanca: AGA, p. 565-577.

Pedrão E, Arai M, Barrilari IMR AND CARVAlho IS. 1993a. Análise palinológica de uma amostra de superfície de Querru (Formação Itapecuru), Município de Itapecuru Mirim-MA. Rio de Janeiro: Petrobras, $11 \mathrm{p}$. (Relatório Técnico).

Pedrão E, Arai M, Carvalho IS ANd Ferreira CS. 1993b. Palinomorfos de sedimentos albianos (Formação Itapecuru) da Bacia do Parnaíba. Rio de Janeiro: Petrobras, 13 p. (Relatório Técnico).

Pedrão E, Arai M, Carvalho IS and Santos MHB. 1993c. Palinomorfos da Formação Itapecuru - análise palinológica de uma amostra de superfície da Ponta do Farol, São Luís-MA. Rio de Janeiro: Petrobras, 10 p. (Relatório Técnico).

Pereira AA ANd Medeiros MA. 2008. A new Sclerorhynchiform (Elasmobranchii) from the middle Cretaceous of Brazil. Rev Bras Paleontol 11(3): 207-212.

PEYER B. 1924. Ergebnisse der Forschungsreisen Prof. E. Stromer in der Wüsten Ägyptens. II. Wirbeltier reste der Baharije Stufe (unterstes Cenoman) 6, Die Ceratodus Funde. Abh Bayer Akad Wiss Math, Natur Abt, München 30: $1-23$.

RAGE JC. 1988. Gondwana, Tethys and terrestrial vertebrates during the Mesozoic and Cainozoic. In: AUDLEYCharles MG and Hallam A (Eds), Gondwana and Tethys, Geol Soc Special Publication, p. 255-273.
REYMENT RA AND Dingle RV. 1987. Paleogeography of Africa during the Cretaceous Period. Palaeogeogr Palaeoclimatol Palaeoecol 59: 93-116.

Richter M And Toledo CEV. 2008. The first Triassic lungfish from South America (Santa Maria Formation, Paraná Basin) and its bearing on geological correlations within Pangaea. Geol Soc Lon Spec Publ 295: 43-54.

Rossetti DF. 2001. Arquitetura deposicional da Bacia de São Luís-Grajaú. In: Rossetti DF, GóES AM AND TRUCKEnBRodT W (Eds), O Cretáceo na Bacia de São Luís - Grajaú, Belém: Mus Para Emílio Goeldi, p. 31-46.

Rossetti DF. 2003. Bacia de São Luís-Grajaú. Bol Fund Phoenix 58: 1-9.

Rossetti DF, Góes AM And Truckenbrodt W (EDs). 2001. O Cretáceo na Bacia de São Luis-Grajaú. $1^{\mathrm{a}}$ ed., Belém: Editora do Mus Para Emílio Goeldi, 264 p.

Rossetti DF And Toledo PM. 1996. Cenomanian climate in northern Brazil: evidences from sedimentary features in the Upper Itapecuru Formation. An Acad Bras Cienc 68: 139-147.

Rossetti DF And TRUCKenbrodt W. 1997. Revisão estratigráfica para os depósitos do Albiano - Terciário Inferior (?) na bacia de São Luís (MA), norte do Brasil. Bol Mus Para Emílio Goeldi, Ser Cienc da Terra 9: 29-41.

RuSSELL DA. 1996. Isolated dinosaur bones from the middle Cretaceous of the Tafilalt, Morocco. Bull Mus Natl Hist Nat, Paris, $4^{\text {th }}$ ser., 18, Section C (2-3): 349 402.

Schultze HP. 1991. Lungfish from the El Molino (Late Cretaceous) and Santa Lucia (Early Paleocene) formations in southcentral Bolivia. Rev Tec YPFB 12(3-4): 441-448.

Sereno PC, Dutheil DB, Larochene M, LARSSon HCE, Lyon GH, MAGWEne PM, Sidor CA, VARriCHIO DJ AND WILSON JA. 1996. Predatory dinosaurs from the Sahara and Late Cretaceous faunal differentiation. Science 272: 986-991.

Sereno PC, Wilson JA AND Conrad JL. 2004. New dinosaurs link southern landmasses in the mid-Cretaceous. Proc R Soc Lond 271: 1325-1330.

Silva VG And Azevedo SAK. 1996. Um dipnóico da Formação Brejo Santo, Jurássico da Chapada do Araripe, Ceará, Brasil. An Acad Bras Cienc 64: 419-420.

Smith MM. 1984. Petrodentine in Extant and Fossil Dipnoan Dentitions: Microstructure, Histogenesis and Growth. Proc Linn Soc N S W 107(3): 367-407.

Soto M AND Perea D. 2010. Late Jurassic Lungfishes (Dipnoi) from Uruguay, with Comments on the System- 
atics of Gondwanan Ceratodontiforms. J Vert Paleontol 30(4): 1049-1058

Stromer E. 1915. Ergebnisse der forschungsreisen Prof. E. Stromers in den Wüsten-Ägyptens. II - WirbeltierReste der Baharîje-Stufe (unterstes Cenoman). 3 - Das original des theropoden Spinosaurus aegyptiacus nov. gen., nov. spec. Abh Kön Bayer Akad Wiss 28(3): 1-32.

Stromer E. 1931. Ergebnisse der forschungsreisen Prof. E. Stromers in den Wüsten-Ägyptens. II - WirbeltierReste der Baharîje-Stufe (unterstes Cenoman). 10 - Ein skellet-rest Carcharodontosaurus nov. gen. Abh Kön Bayer Akad Wiss, N F 9: 1-23.

Stromer E. 1934. Ergebnisse der forschungsreisen Prof. E. Stromers in den Wüsten-Ägyptens. II - WirbeltierReste der Baharîje-Stufe (unterstes Cenoman). 13 - Dinosauria. Abh Kön Bayer Akad Wiss, N F 22: 1-79.

TABAste N. 1963. Études de restes de poissons du Cretácé saharien. Mem Inst Fr Afr Noire 68: 436-485.
Toledo CEV, Bertini RJ, Sousa EP And Medeiros MA. 2005. First occurrence of Protopterus humei (Dipnoiformes) in South America. In: CONGRESSO LATINOAmericano de Paleontologia de Vertebrados, 2, Rio de Janeiro. Boletim de Resumos, Rio de Janeiro: Museu Nacional, p. 262-263.

Vilas BôAS IC AND CARVAlho IS. 2001. Répteis marinhos (Mosasauria e Plesiosauria) do Cretáceo Superior da Bacia de São Luís (Maranhão, Brasil). In: Rossetti DF, Góes AM And TRuckenbrodt W (Eds), O Cretáceo na Bacia de São Luís-Grajaú, Belém: Mus Para Emilio Goeldi, p. 223-233.

Vilas Bôas IC, Carvalho IS, Medeiros MA AND Pontes H. 1999. Dentes de Carcharodontosaurus (Dinosauria, Tyrannosauridae [sic]) do Cenomaniano, Bacia de São Luís (Norte do Brasil). An Acad Bras Cienc 71: 846-847. 